\title{
METHODS OF CONFIGURING THE DECISION-MAKING SYSTEM WHEN CHOOSING AND SUPPORTING AN ENTITY DEVELOPMENT STRATEGY
}

Victor V. MARSHIROV

Associate Professor, Department of Information Systems and Technologies, National Research University Higher School of Economics

Address: 25/12, Bolshaya Pecherskaya Street, Nizhniy Novgorod, 603155, Russian Federation E-mail:vmarshirov@hse.ru

\section{Larisa E. MARSHIROVA}

Associate Professor, Department of Accounting, Analysis and Audit, National Research University Higher School of Economics

Address: 25/12, Bolshaya Pecherskaya Street, Nizhniy Novgorod, 603155, Russian Federation E-mail: Imarshirova@hse.ru

This article is devoted to the problems of formalization of decision-making in the choice of development strategy in an organization and the ways to implement this strategy. A prioritization method is proposed that allows converting qualitative indicators into qualitative variables by means of pairwise comparison of the objects. As opposed to a simple summation of estimates preferences, this computational algorithm allows one to take into account indirect benefits of all the objects under consideration. The approaches to the ranking of experts and challenges an organization faces at various stages of its development are set forth.

The algorithm is validated on the example of a particular company. The estimates of the priorities of experts are provided; the tree of tasks for which the comprehensive priorities are designed (taking into account the importance and relevance of expert tasks for each expert) is constructed; the analysis of the results for different conditions of the external and internal environment of the organization is made. Recommendations are given on the choice of the deviation values for matrix of pairwise comparisons of objects, as well as a reasonable number of iterations of the calculation of the integrated power of these objects.

The practical significance of the work lies in the fact that the proposed algorithm and methodology for ranking of experts, tasks and subtasks may be used to prepare management accounting regulations to improve decision-making methods, taking into account the strategic and tactical objectives of the organization.

Key words: prioritization method, management accounting, decision-making, strategy, experts, tree of tasks.

Citation: Marshirov V.V., Marshirova L.E. (2015) Methods of configuring the decision-making system when choosing and supporting an entity development strategy. Business Informatics, no. 4 (34), pp. 47-54.

DOI: $10.17323 / 1998-0663.2015 .4 .47 .54$.

\section{Introduction}

$\mathrm{E}$ ach entity should have an effective strategy for its successful development, i.e. a development plan for an extended time frame. The significance of strategic management increases in the context of tough competition and a complicated economic situation in the country. The management of a company should ensure fast adaptation of the entity to the changing conditions. The strategy of each entity is unique, as it depends on many factors: business goals, attractiveness of goods, works and services offered, the state of market outlets, 
the behavior of competitors, suppliers and customers, production engineering, resources availability and more.

Most often the search for and improvement of development options of an enterprise takes place using brainstorming sessions by business owners and the management team of an entity. However, this process is usually the subject of much controversy. It requires a lot of time for coordination and frequently depends on the authority of the leader, who may authoritatively force the remaining participants of the discussion to make a wrong decision that ignores opinions of all sides involved. When implementing a strategy, financial, human and material resources are frequently deficient, because the plan is to solve all the problems facing an entity at once. The complexity of strategy elaboration and ways of implementing it is also complicated by the fact that various factors affecting this choice are of qualitative or probabilistic nature.

This article suggests a method that can be used to formalize the strategy selection of an enterprise development with due consideration to opinions of all persons involved in decision-making, to rank tasks that must be resolved for implementation of strategy, and regularly to correct this process taking into account problems encountered or new realities.

\section{Method of prioritization}

In order to improve decision-making processes when choosing ways to implement the strategy of an entity, it is suggested that one address the method of ranking the experts involved and tasks to be solved. A method of prioritization [1] is used in this method. Prioritization assumes pair-wise comparison of objects and filling in the pair-wise comparison matrix $M=\left\|m_{i j}\right\|$, wherein at the intersection of the row $i$ and the column $j$ the preference estimate of the object $i$ over the object $j$ must be specified. This estimate is determined as follows:

$m_{i j}=\left\{\begin{array}{l}1+y, \text { if the object } i \text { is more preferable than the object } j ; \\ 1, \text { if the objects } i \text { and } j \text { are equivalent } ; \\ 1-y, \text { if the object } j \text { is more preferable than the object } i,\end{array}\right.$ where $y$ is the deviation of elements of the matrix $M$, which falls within the limits $0<y<1$.

Thereafter, for each object $i$ the integrated force of the first order $F_{i}(1)$ must be calculated by summing up its preference estimates for the corresponding line:

$$
F_{i}(1)=\sum_{j=1}^{n} m_{i j},
$$

where $n$ is the number of the objects.
These integrated forces of the first order can be represented as a vector for all the objects being compared

$$
F(1)=\left[F_{1}(1), F_{2}(1), \ldots, F_{i}(1), \ldots, F_{n}(1)\right] .
$$

However, the index of an integrated force of the first order of the object $i F_{i}(1)$ does not consider the «force» of other objects, being «won» by the object $i$ or «lost» by the object $j$ in the comparison. Therefore, in order to obtain more precise estimates for each object, one determines the integrated force of the second order with consideration of «forces» of all objects being compared:

$$
F_{i}(2)=\sum_{j=1}^{n} m_{i j} F_{i}(1),
$$

where $i=j=\overline{1, n}$, and $n$ is the number of objects.

Further iterations are made in a similar way, and integrated forces of the $k$ order are calculated using the following formula in the matrix form:

$$
F(k)=M F(k-1),
$$

where $F(0)=(1,1, \ldots 1)$.

This computation algorithm, which is unlike the simple summation of preference estimates, provides consideration of side advantages of all other objects being compared (the issue of iterations quantification will be discussed in Section 3).

For convenience of use and opportunity of comparison, integrated forces of objects of the $k$ order are normalized, i.e., are presented within the scale with a fixed sum of estimates equal to one:

$$
F_{i}^{r e l}(k)=\frac{F_{i}(k)}{\sum_{i} F_{i}(k)},
$$

where $F_{i}^{\text {rel }}(k)$ is the normalized integrated force (priority) of the $k$ order of the object $i$.

$$
\text { Since } \sum_{i=1}^{n} F_{i}^{r e l}(k)=1,
$$

the numerical value of priority $F_{i}^{\text {rel }}(k)$ represents the relative degree of preference of the object $i$ over all other objects being compared.

\section{Formulation of the task}

Let's consider the use of the method of prioritization on the example of one enterprise in the city of Nizhny Novgorod. The enterprise mentioned has been producing tools for already over ten years. During this time, the enterprise was able to conquer a broad market outlet, but in mid-2014 its profits began to decline. Therefore, the owners decided to identify factors of the deteriorating 
performance of the company. Five major reasons for loss of work of the entity were identified: errors in the sales policy resulting in the loss of several important customers; growth of overhead expenses; several kinds of products running at a loss; failures in the processing equipment operation resulting in increased down time and repair costs; increased spoilage in production. In other words, the enterprise was in a pre-crisis state.

To prevent further decline in profits, it was necessary to correct the development strategy of the entity. However, discussion of feasible strategies showed that each owner and each top manager had his own preferences in choosing the plan for the way out of the situation. Therefore, in this situation it was decided to use the method of prioritization.

When choosing a development strategy for the entity, the following stages were subsequently implemented:

$\downarrow$ appointment of experts and their ranking by assigning weighting indexes to each expert;

$\downarrow$ formation of the tasks and subtasks tree to implement the strategy of the entity;

task ranking by each expert using the method of prioritization;

$\downarrow$ computation of the integrated priority of each task on the basis of experts' priorities and the task's importance for each expert.

\section{Ranking experts}

Two owners (denoted S1 and S2) and three chief executives: the director (D), the deputy director (DD) and the financial director (FD) were experts for choosing the organization's strategy and ways of implementing it. The owners compiled a matrix of experts pair-wise comparison for ranking experts $M=\left\|m_{i j}\right\|$, where

$$
m_{i j}=\left\{\begin{aligned}
& 1+y, \text { if the expert } i \text { has greater importance } \\
& \text { in decision making than the expert } j \\
& 1, \text { if the experts } i \text { and } j \text { have equal } \\
& \text { importance in decision making; } 1-y, \text { if the expert } j \text { has greater importance } \\
& \text { in decision making than the expert } i .
\end{aligned}\right.
$$

It was decided to determine the deviation value $y$ in conformity with Table 1.

Let's consider each option in more detail.

The first option is used when the owners consider that the importance of their estimates substantially exceeds the importance of estimates of other experts. In such a case, e.g., the following ratios are composed:
Deviation value of elements

Table 1.

\begin{tabular}{|c|c|c}
\hline Option & $\begin{array}{c}\text { Difference in the degree } \\
\text { of experts significance } \\
\text { in decision-making }\end{array}$ & Deviation value $(\boldsymbol{y})$ \\
\hline 1 & high & $0.9-0.95$ \\
\hline 2 & average & 0.5 \\
\hline 3 & low & $0.1-0.2$ \\
\hline
\end{tabular}

$\mathrm{S} 1=\mathrm{S} 2>>\mathrm{D}=\mathrm{DD}=\mathrm{FD}$ or $\mathrm{S} 1=\mathrm{S} 2>>\mathrm{D}>\mathrm{DD}=\mathrm{FD}$ or $\mathrm{S} 1=\mathrm{S} 2>>\mathrm{D}>\mathrm{DD}>\mathrm{FD}$ and others. In other words, knowledge, experience, intuition, willingness to take responsibility in management decision-making of the owners (S1 and S2) is significantly higher than that of the hired personnel (D, DD, FD), since the sign «>>» is present.

The first option should also be used if the owners consider that the importance of estimates of one or more experts of the hired personnel must be considerably increased, i.e. other inequalities are composed, but therein the sign $《\rangle>\gg$ is still present: $\mathrm{D}>>\mathrm{S} 1=\mathrm{S} 2>\mathrm{DD}>\mathrm{FD}$ or $\mathrm{D}=\mathrm{FD}>>\mathrm{S} 1>\mathrm{S} 2>\mathrm{DD}$ or $\mathrm{D}>>\mathrm{FD}>\mathrm{S} 1=\mathrm{S} 2>\mathrm{DD}$ and others.

The specific value of $y$ is set on the basis of practical considerations.

The second option is expedient to use if the owners when estimating the significance of all experts consider that none of them fits in significantly against others. For example: $\mathrm{S} 1=\mathrm{S} 2>\mathrm{D}>\mathrm{DD}>\mathrm{FD}$ or $\mathrm{S} 1>\mathrm{S} 2>\mathrm{D}=$ $\mathrm{DD}>\mathrm{FD}$ or $\mathrm{S} 1=\mathrm{S} 2>\mathrm{D}>\mathrm{FD}>\mathrm{DD}$ and others. It is apparent that in these ratios the signs $\langle>\rangle$ » are missing and the signs « $>$ » prevail, i.e. the difference in the degree of experts' significance in decision-making is average, so in conformity with Table $1 y=0.5$.

The third option is selected in expert ranking by the degree of their significance when the signs «>>» are missing, and the signs «=» prevail. For example: $\mathrm{S} 1=\mathrm{S} 2>\mathrm{D}=\mathrm{DD}=\mathrm{FD}$ or $\mathrm{S} 1>\mathrm{S} 2=\mathrm{D}=\mathrm{DD}=\mathrm{FD}$ or $\mathrm{S} 1=\mathrm{S} 2=\mathrm{D}=\mathrm{DD}>\mathrm{FD}$ and others. In this case, in conformity with Table 1 , it is proposed to use $y=0.1-0.2$.

Table 2 shows the results of experts' priorities (weights) computation which was made in mid-2014 for the inequality $\mathrm{S} 1=\mathrm{S} 2>>\mathrm{D}>\mathrm{DD}=\mathrm{FD}$. In other words, the owners of the entity assumed for themselves the highest priority when choosing a strategy in comparison with hired managers, and assigned to the director of the entity a higher priority than to the deputy director for operations and to the financial director. Therefore, according to Table $1 \quad y=0.9$. 
Table 2.

Results of priorities (weights) computation of five experts who will choose the development strategy of the entity and ways of implementing it

\begin{tabular}{c|c|c|c|c|c|c|c|c|c|c|c|c|c}
\hline$i \backslash j$ & $S 1$ & $S 2$ & $D$ & $D D$ & $F D$ & $F(1)$ & $F^{\text {rel }}(1)$ & $F(2)$ & $F^{\text {rel }}(2)$ & $F(3)$ & $F^{\text {rel }}(3)$ & $F(4)$ & $F^{\text {rel }}(4)$ \\
\hline S1 & 1 & 1 & 1.9 & 1.9 & 1.9 & 7.7 & 0.31 & 33.64 & 0.37 & 113.24 & 0.36 & 388.11 & 0.36 \\
\hline S2 & 1 & 1 & 1.9 & 1.9 & 1.9 & 7.7 & 0.31 & 33.64 & 0.37 & 113.24 & 0.36 & 388.11 & 0.36 \\
\hline $\mathrm{D}$ & 0.1 & 0.1 & 1 & 1.9 & 1.9 & 5 & 0.20 & 10.91 & 0.12 & 42.87 & 0.14 & 145.69 & 0.14 \\
\hline DD & 0.1 & 0.1 & 0.1 & 1 & 1 & 2.3 & 0.09 & 6.64 & 0.07 & 21.10 & 0.07 & 69.13 & 0.07 \\
\hline FD & 0.1 & 0.1 & 0.1 & 1 & 1 & 2.3 & 0.09 & 6.64 & 0.07 & 21.10 & 0.07 & 69.13 & 0.07 \\
\hline \multicolumn{8}{|c|}{ Total } \\
\hline
\end{tabular}

The first six columns in Table 2 represent the pair-wise comparison matrix of experts in conformity with the basic formula of the method of prioritization. By summing up the preference estimates in each row, one determines the integrated force of the first order for each expert $F(1)$, which is subsequently normalized to obtain estimates of all experts in fractions of one $F^{\text {rel }}(1)$. In order to obtain more accurate estimates for each expert, the integrated forces of the second, third and fourth orders $F(2), F(3), F(4)$ are calculated by the described algorithm, and these are also normalized.

It follows from Table 2 that after the fourth iteration the weight (priority) of the first two experts was $36 \%$, which is more than 2.5 times higher than the priority of the director of the entity and more than 5 times higher than the weight of his deputies.

After the third iteration, the priority values stopped changing, so 3-4 iterations of corresponding computations can be recommended for practical use.

\section{Procedures \\ of expert ranking of entity growth option}

The owners of the company and its top executive management formulated the prime target that they set for themselves: the withdrawal of the enterprise from pre-crisis status to a higher level of development. To achieve this target with due consideration of all expert opinions, five prime tasks that must be solved were identified: cost savings $(\mathrm{C} 1)$, increased income $(\mathrm{C} 2)$, search for financial resources (C3), new production output (C4), improvement of the management system (C5).

But before the experts evaluate them, it is necessary to develop the tree of subtasks to be solved for implementation of each direction of the entity development.
Only in this case can the experts be sure that they equally understand the structure of each task, measures for its achievement, possible risks and restrictions. Therefore, each of the five formulated tasks was structured in Table 3 below, i.e. the subtasks tree of the first and second levels was developed. Estimates of the resource requirements (financial, human, material) were prepared for each subtask but many of those estimations were of probabilistic nature.

At the next stage, each expert composed the pair-wise comparison matrix of tasks from Table 3 by the algorithm described in section 1. It was decided to determine the deviation value of elements of these matrices in accordance with Table 4.

If the expert considers that one or more tasks are considerably more important than the others, he composes, e.g. the inequality: $\mathrm{C} 1=\mathrm{C} 2>>\mathrm{C} 3>\mathrm{C} 4>\mathrm{C} 5$ or $\mathrm{C} 4>\mathrm{C} 2>\mathrm{C} 3>>\mathrm{C} 1>\mathrm{C} 5$ or $\mathrm{C} 3=\mathrm{C} 5>\mathrm{C} 2>$ $\mathrm{C} 1 \gg>\mathrm{C} 4$ or others, wherein at least one sign $« \gg\rangle »$ is present. On the basis of this inequality, the adjacency matrix will be compiled, wherein $y=0.9-0.95$. If, according to an expert, the tasks have approximately equal significance, then $y=0.1-0.2$. In all other cases, the adjacency matrix will be compiled with the deviation value equal to 0.5 . Table 5 shows the inequalities on the basis of which the experts compiled their adjacency matrices in the middle 2014.

When processing the matrices obtained from the experts, the order equal to four was used. The normalized integrated force of each task was determined by the same formulas that have been described above when calculating the significance of each expert. The computation results are summarized in Table 6, and then in the same table all five tasks were ranked taking into account the experts' priorities and the task's importance for each expert. 
Table 3.

Tasks and subtasks tree for implementation of the entity's strategy

\begin{tabular}{|c|c|c|}
\hline Tasks & Subtasks of the first level & Subtasks of the second level \\
\hline \multirow{8}{*}{ 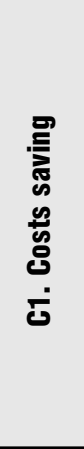 } & \multirow{4}{*}{ Reduction of production cost } & $\begin{array}{l}\text { Reduction of direct costs (material savings, spoilage reduction, quality control of materials when received } \\
\text { from suppliers, improvement of the worker remuneration system) }\end{array}$ \\
\hline & & $\begin{array}{l}\text { Reduction of overhead costs (elimination of redundant functions of management personnel; improvement of the } \\
\text { remuneration system, particularly bonuses, appraisal and reduction of production management personnel) }\end{array}$ \\
\hline & & Introduction of efficient management accounting of expenses and net cost of finished production \\
\hline & & Transfer of cost-based production functions to outsourcing \\
\hline & \multirow{4}{*}{$\begin{array}{l}\text { Reduction of unprofitable } \\
\text { production }\end{array}$} & Refusal to carry loss-making assortment of finished production \\
\hline & & Certification and reduction of production personnel \\
\hline & & Lease of vacated premises and equipment \\
\hline & & Sale of unnecessary equipment \\
\hline \multirow{4}{*}{ 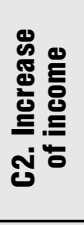 } & \multirow{2}{*}{$\begin{array}{l}\text { Increase in sales revenue } \\
\text { offinished products }\end{array}$} & $\begin{array}{l}\text { Search for new customers (marketing development, flexible discount system, participation in tenders to } \\
\text { purchase tools for state needs) }\end{array}$ \\
\hline & & Price increase for some types of products (sales analysis, analysis of current market prices in the region) \\
\hline & \multirow{2}{*}{ Increase in other sales } & Sale of unused materials (inventory of stocks, search for buyers) \\
\hline & & Sale of unused fixed assets (preparation for sale, substantiation of selling price, search for buyers) \\
\hline \multirow{6}{*}{ 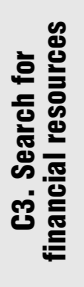 } & \multirow{3}{*}{$\begin{array}{l}\text { Receiving favorable } \\
\text { financing }\end{array}$} & Bank credits (monitoring terms and interest rates, developing competent business plans) \\
\hline & & Loans (from partner companies, private individuals including the owners) \\
\hline & & Commercial credits obtaining from suppliers and contractors \\
\hline & \multirow{3}{*}{ Reduction of receivables } & Ongoing analysis of accounts receivable and work to prevent overdue debts \\
\hline & & Law suits against debtors related to overdue account receivables \\
\hline & & Sale of bad debts to collection agencies \\
\hline \multirow{7}{*}{ 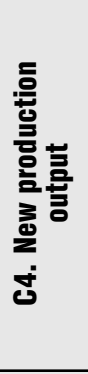 } & $\begin{array}{l}\text { Selection of a new range } \\
\text { of products }\end{array}$ & Complex of research and development activities \\
\hline & \multirow{4}{*}{$\begin{array}{l}\text { Preparation for serial } \\
\text { production of new products }\end{array}$} & Purchase and installation of equipment, new materials and components \\
\hline & & Development of standards and regulations \\
\hline & & Personnel training \\
\hline & & Advertising \\
\hline & \multirow{2}{*}{$\begin{array}{l}\text { Search for new contractual } \\
\text { partners }\end{array}$} & Search for suppliers, contractors (analysis of prices, quality of supplied materials, works and services) \\
\hline & & Search for buyers (analysis of prices, flexible discount system, advertising) \\
\hline \multirow{8}{*}{ 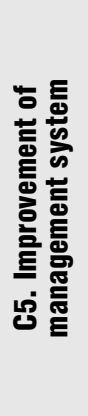 } & \multirow{2}{*}{ Introduction of budgeting } & Development of the financial model of entity, allocation of financial responsibility centers \\
\hline & & Development of planning regulations, accounting, analysis and plans revision \\
\hline & \multirow{2}{*}{$\begin{array}{c}\text { Changing the employees' } \\
\text { incentive system }\end{array}$} & Development of new regulations for material incentives of employees \\
\hline & & Development of new regulations for non-financial recognition of employees \\
\hline & \multirow{2}{*}{$\begin{array}{l}\text { Reduction of administrative } \\
\text { staff }\end{array}$} & Regular appraisal of the managerial staff \\
\hline & & Substantiation of the number of managerial staff and reduction of inefficient managers \\
\hline & \multirow{2}{*}{$\begin{array}{l}\text { Reduction of commercial and } \\
\text { administrative expenses }\end{array}$} & $\begin{array}{l}\text { Analysis of transport, business travel and entertainment expenses; expenses for advertising, office and } \\
\text { warehouse space maintenance, and their optimization }\end{array}$ \\
\hline & & Transfer of cost-based management functions to outsourcing \\
\hline
\end{tabular}

Deviation value of elements of the pair-wise comparison matrix

Table 4.

\begin{tabular}{c|c|c}
\hline Option & Difference in the degree of task importance for a particular expert & Deviation value $(\boldsymbol{y})$ \\
\hline 1 & high & $0.9-0.95$ \\
\hline 2 & average & 0.5 \\
\hline 3 & low & $0.1-0.2$ \\
\hline
\end{tabular}


Table 5.

Tasks ranking by experts and choosing the deviation value of the adjacency matrix

\begin{tabular}{c|c|c} 
Experts & Tasks ranking & Deviation value of the adjacency matrix (y) \\
\hline The first owner (S1) & $\mathrm{C} 4>\mathrm{C} 2>\mathrm{C} 1=\mathrm{C} 3=\mathrm{C} 5$ & 0.9 \\
\hline The second owner (S2) & $\mathrm{C} 1=\mathrm{C} 2=\mathrm{C} 4>\mathrm{C} 3=\mathrm{C} 5$ & 0.2 \\
\hline Director (D) & $\mathrm{C} 1=\mathrm{C} 2=\mathrm{C} 5>\mathrm{C} 3>\mathrm{C} 4$ & 0.5 \\
\hline Deputy director (DD) & $\mathrm{C} 4>\mathrm{C} 1=\mathrm{C} 5>\mathrm{C} 2>\mathrm{C} 3$ & 0.9 \\
\hline Financial Director (FD) & $\mathrm{C} 1>\mathrm{C} 2>\mathrm{C} 3=\mathrm{C} 4>\mathrm{C} 5$ & 0.5 \\
\hline
\end{tabular}

Table 6.

Results of tasks ranking by each expert and the integrated priority of each task

\begin{tabular}{|c|c|c|c|c|c|c|c|c|c|c|c|c|}
\hline \multirow{3}{*}{ Task } & \multicolumn{10}{|c|}{ Experts } & \multirow{3}{*}{ Priority } & \multirow{3}{*}{ Place } \\
\hline & \multicolumn{2}{|c|}{ A1 } & \multicolumn{2}{|c|}{ A2 } & \multicolumn{2}{|c|}{ D } & \multicolumn{2}{|c|}{ DD } & \multicolumn{2}{|c|}{ FD } & & \\
\hline & 0.37 & place & 0.37 & place & 0.14 & place & 0.07 & place & 0.07 & place & & \\
\hline $\mathrm{C} 1$ & 0.11 & 3-5 & 0.22 & $1-3$ & 0.24 & $1-3$ & 0.21 & $2-3$ & 0.29 & 1 & 0.19 & 3 \\
\hline C2 & 0.22 & 2 & 0.22 & $1-3$ & 0.24 & $1-3$ & 0.07 & 4 & 0.24 & 2 & 0.21 & 2 \\
\hline $\mathrm{C} 3$ & 0.11 & 3-5 & 0.18 & $4-5$ & 0.15 & 4 & 0.04 & 5 & 0.17 & 3-4 & 0.14 & 5 \\
\hline C4 & 0.44 & 1 & 0.22 & $1-3$ & 0.12 & 5 & 0.47 & 1 & 0.17 & $3-4$ & 0.30 & 1 \\
\hline C5 & 0.11 & $3-5$ & 0.18 & $4-5$ & 0.24 & $1-3$ & 0.21 & $2-3$ & 0.12 & 5 & 0.16 & 4 \\
\hline Total & 1.00 & & 1.00 & & 1.00 & & 1.00 & & 1.00 & & 1.00 & \\
\hline
\end{tabular}

It is apparent that the following information is contained in Table 6 for each expert:

$\downarrow$ the priority that he got at the previous stage of computation (see Table 2), e.g., for owners (A1 and A2) 0.37 ;

task priorities $(\mathrm{C} 1-\mathrm{C} 5)$, which have been computed on the basis of the pair-wise comparison matrix, e.g., for the general director (D) it is $0.24,0.24,0.15$, 0.12 and 0.24 ;

$\checkmark$ the place of each task in the ranking composed by an expert, e.g., the financial director (FD) in the first place assigned the task of costs saving $(\mathrm{Cl})$, in the second increase of income (C2), in the last place - improvement of the management system (C5), while the tasks related to search for financial resources (C3) and the need for new production output $(\mathrm{C} 4)$ - share the third and the fourth places.

The penultimate column of Table 6 contains the integrated priority of each task which has been calculated taking into account the significance of experts and the importance of this task for each expert. It is apparent that the main task for the implementation of the company's strategy is $\mathrm{C} 4$ (the need for new production output), which is more than two times more important than task C3 (search for financial resources), which has the lowest priority.
Clearly, for the withdrawal of the enterprise from precrisis status it is necessary to solve all five formulated tasks, however, the lack of material, labor, financial and timing resources requires determination of the direction of the «main effort», of that task, which has bigger importance. Each time, making managerial decisions on the distribution of limited resources when developing an action plan for a quarter, month, week, the organization's chief executives and owners had exact priorities for the choice stated in Table 6.

In early November 2014, the enterprise started production of new types of products, and several important subtasks in other directions were successfully implemented as well. For this reason, a revision of task priorities was required. This time, the owners decided to raise the significance of the experts - heads of the entity, and the inequality $\mathrm{S} 1=\mathrm{S} 2>\mathrm{D}=\mathrm{DD}=\mathrm{FD}$ was used. In addition, amendments and changes were made in the tasks and subtasks tree, although the task list remained unchanged. Using the algorithms described above, the tasks of costs saving (C1) and improvement of management system (C5) were the first and the second in the ranking.

The entity has gradually accumulated positive experience of applying the method of prioritization. A clear algorithm and the simplicity of the method implemen- 
tation made it possible to develop corporate regulations and to implement ranking not only of tasks, but also of subtasks of the first level, involving heads of departments on an expert basis. The time was reduced for discussion and choosing managerial solutions; the possibility appeared to compare not only quantitative, but also qualitative indicators. The profit of the entity in the second half of 2014 as compared to the first half of the same year increased by $28 \%$. The main target of withdrawing the enterprise from the pre-crisis state was achieved.

At the end of 2014 due to changes in the economic situation in the country, the entity once again had to revise the task priorities. This time the need to search for financial resources was recognized as the most important task, while the task of releasing new types of products was excluded from discussion. Financial and legal departments developed a detailed subtask tree in order to obtain additional sources of funding, and subtasks of the first and second levels were ranked using the method of prioritization.

The authors of this article did not have as their goal to improve the Saaty method [2], wherein a rating scale from 1 to 9 is used for objects comparison. These estimates have the following values: 1 - equal importance, 3 moderate superiority of one above the other, 5 - substantial superiority of one above the other, $7-$ drastic superiority of one above the other, 9 - very strong superiority of one above the other; 2, 4, 6, 8 - corresponding intermediate values. If during the pair-wise comparison, an expert considers that the object $i$ considerably exceeds the object $j$, then in the pair-wise comparison matrix $B=\left\|b_{i j}\right\| b_{i j}=3$, and $b_{j i}=1 / 3$. The method of prioritization is just one of possible modifications of the Saaty method.

The authors believe that for an expert, when comparing objects it is easier to answer «better (more important, preferred)», «worse (less important or less preferred)», «equal», than using the scale from 1 to 9 to assign instead the grade 6 , e.g. the grade 8 and to be wrong. For this reason, the ranges of parameter $y$ proposed in Tables 1 and 4 must consider that the spread of estimates can be evaluated prior to the objects comparison. Certainly, the ranges of parameter $y$ and the number of these ranges are only recommended, and thereafter it is possible to correct them depending on the current situation and on the standing tasks.

\section{Conclusion}

Consequently, the authors have obtained the following results:

$\diamond$ a new approach has been suggested to the procedure of choosing an entity's development strategy and ways of implementing this strategy;

$\diamond$ the algorithm of the method of prioritization has been developed, making it possible to compare objects by qualitative factors and obtain quantitative estimates;

$\diamond$ procedures for ranking experts and tasks that an entity faces at various stages of its development have been proposed;

$\diamond$ the validation of the algorithm has been implemented using a particular enterprise: the estimates of experts' priorities have been presented; a task tree has been composed for which integrated priorities have been computed with due consideration of experts' significance; an analysis has been carried out of the results obtained for different conditions of external and internal environment of an entity.

The practical significance of the work lies in the fact that the proposed algorithm and the method of ranking experts and tasks can be used to prepare management accounting regulations to improve decision making methods with due account of the strategic and tactical tasks of an entity.

\section{References}

1. Marshirov V.V., Marshirova L.E. (2013) Kompleksnaya otsenka individual'nogo truda razrabotchikov programmnogo obespecheniya [Comprehensive evaluation of individual work of software developers]. Business Informatics, no. 2 (24), pp. 55-62 (in Russian).

2. Saaty T.L. (2001) Decision making for leaders: The Analytic Hierarchy Process for decisions in a complex world. Pittsburgh, PA: RWS Publications. 


\title{
МЕТОДИКА ОРГАНИЗАЦИИ СИСТЕМЫ ПРИНЯТИЯ РЕШЕНИЙ ПРИ ВЫБОРЕ И ПОДДЕРЖКЕ СТРАТЕГИИ РАЗВИТИЯ ОРГАНИЗАЦИИ
}

\section{В.В. МАРШИРОВ}

кандидат технических наук, доцент кафедры информационных систем и технологий, Национальный исследовательский университет «Высшая школа экономики» Адрес: 603155, г. Нижний Новгород, ул. Большая Печерская, 25/12 E-mail:vmarshirov@hse.ru

\section{Л.Е. МАРШИРОВА}

кандидат экономических наук, доцент кафедры бухгалтерского учета, анализа и аудита, Национальный исследовательский университет «Высшая школа экономики»

Адрес: 603155, г. Нижний Новгород, ул. Большая Печерская, 25/12 E-mail:Imarshirova@hse.ru

\begin{abstract}
Статья посвящена проблемам формализации процессов принятия решений при выборе стратегии развития организации и путей реализации этой стратегии. Предложен методрасстановкиприоритетов, который позволяет путем попарного сравнения объектов переводить качественные показатели в количественные. Этот алгоритм расчета, в отличие от простого суммирования оценок предпочтения, позволяет учесть косвенные преимущества всех других объектов, с которыми производилось сравнение. Изложены подходы к ранжированию экспертов и задач, которые стоят перед организацией на разных этапах ее развития.

Проведена апробация алгоритма на примере конкретного предприятия: представлены расчеты приоритетов экспертов, построено дерево задач, для которых рассчитаны комплексные приоритеты с учетом значимости экспертов и значимости задач для каждого эксперта, а также проведен анализ полученных результатов для различных условий внешней и внутренней среды организации. Даны рекомендации по выбору значений величины отклонений матриц парных сравнений объектов и обосновано количество итераций при расчете интегрированной силы этих объектов.

Практическая значимость работы заключается в том, что предложенные алгоритм и методика ранжсирования экспертов, задач и подзадач могут быть использованы при подготовке регламентов управленческого учета для совершенствования методов принятия решений с учетом стратегических и тактических задач организации.
\end{abstract}

Ключевые слова: метод расстановки приоритетов, управленческий учет, принятие решений, стратегия, эксперты, дерево целей

Цитирование: Marshirov V.V., Marshirova L.E. Methods of configuring the decision-making system when choosing and supporting an entity development strategy // Business Informatics. 2015. No. 4 (34). P. 47-54.

DOI: 10.17323/1998-0663.2015.4.47.54.

\section{Литература}

1. Марширов В.В., Марширова Л.Е. Комплексная оценка индивидуального труда разработчиков программного обеспечения // Бизнесинформатика. 2013. № 2 (24). С. 55-62.

2. Saaty T.L. Decision making for leaders: The Analytic Hierarchy Process for decisions in a complex world. Pittsburgh, PA: RWS Publications, 2001. $343 \mathrm{p}$. 